\title{
CHARACTERISTICS OF ESR SIGNALS AND TLCLS OF QUARTZ INCLUDED IN VARIOUS SOURCE ROCKS AND SEDIMENTS IN JAPAN: A CLUE TO SEDIMENT PROVENANCE
}

\author{
AIKO SHIMADA ${ }^{1}$, MASASHI TAKADA ${ }^{2}$ and SHIN TOYODA ${ }^{3}$ \\ ${ }^{1}$ JEOL RESONANCE Inc., 1-2 Musashino 3-Chome Akishima Tokyo, 196-8558, Japan \\ ${ }^{2}$ Faculty of Letters, Nara Women's University, Kitauoyanishimachi, Nara, 630-8506, Japan \\ ${ }^{3}$ Department of Applied Physics, Okayama University of Science, 1-1 Ridai, Okayama, 700-0005, Japan
}

Received 1 February 2013

Accepted 26 March 2013

\begin{abstract}
The variation of electron spin resonance (ESR) signal intensities and thermoluminescence colour images (TLCIs) of quartz was investigated in the present study for various rocks and sediments in Japan, to discuss the possibilities of identifying the sediment provenance. The ESR signal intensity of the $\mathrm{E}_{1}{ }^{\prime}$ centre in the same grain size in granitic quartz varies from sample to sample, except for that in Quaternary samples of volcanic sediment, which is very low, close to the noise level. It was found that the diagram, ESR intensities of Al versus Ti-Li centre signal intensities, distinguish volcanic from the same grain size in granitic quartz as well as distinguish individual tephra from another. The TLCIs from volcanic quartz and some granitic quartz samples is almost red and that from the rest of granitic and metamudstone quartz is blue as results of TLCIs although the emission intensities are different.

Our results suggest that examining the multiple-centre signal intensities of ESR and the TLCIs are effective to identify the source of quartz and to estimate the sediment provenance.
\end{abstract}

Keywords: quartz, ESR, TLCI, provenance of sediments, granite, volcanic rocks.

\section{INTRODUCTION}

ESR and luminescence dating of quartz is used for geochronology and geoarchaeology during the Quaternary period (Ikeya, 1993; Aitken, 1985, 1998). Recently another direction of studies for Quaternary earth science has been tested by using ESR or luminescence signals as an indicator of the sediment provenance.

Sediment provenance would give important information on the erosion processes, uplift of the mountains and similar, suggesting the environments at the time of

Corresponding author: A. Shimada

e-mail: ashimada@jeol.co.jp

ISSN 1897-1695 (online), 1733-8387 (print)

(C) 2013 Silesian University of Technology, Gliwice, Poland.

All rights reserved. sediment transportation. It is, however, not easy to clarify it if a peculiar rock does not exist in the drainage basin or the sediment is made of fine grains such as sand and silt. As quartz is one of the most abundant minerals on the surface of the Earth and it is resistant to weathering, sediments usually contain a large amount of quartz. The identification of the provenance of quartz grains would enable the estimation of the provenance of sediments.

Some ESR and luminescence studies on sediment provenance have already been reported. Being initiated by Naruse et al. (1997), the $\mathrm{E}_{1}$ ' centre in quartz was found to be a useful indicator to investigate the provenance of aeolian dust (e.g. Toyoda and Naruse, 2002). Nagashima 
et al. (2007) successfully employed the crystallinity index (CI) in combination with ESR to discriminate two different sources of aeolian dust in the sediment core taken from the Japan Sea. Their work was based on the CI of quartz defined by Murata and Norman (1976), which is obtained from the degree of resolution of the $d$ (212) reflection of quartz at $1.3820 \AA$ on XRD profile. Duttinea et al. (2002) report that quartz of four distinct origins can be distinguished using impurity ( $\mathrm{Al}, \mathrm{Ti}-\mathrm{Li}, \mathrm{Ti}-\mathrm{H}, \mathrm{Ge})$ centres observed after beta irradiation. Shimada and Takada (2008) suggest that the Al, Ti-Li and $\mathrm{E}_{1}$ ' centre signal intensities from natural quartz are useful to distinguish the sediment provenance. Ganzawa et al. (1997) shows that quartz of aeolian origin transported from China can be distinguished from volcanic quartz originated in Japanese tephra by looking at TL colour of quartz grains based on the observation that volcanic quartz emits stronger red thermoluminescence (TL) than blue one whereas plutonic quartz does vice versa (Hashimoto et al., 1986; 1997).

In this study, we report the variation of ESR signal intensities and thermoluminescence colour images (TLCIs; Hashimoto et al., 1986; Ganzawa et al., 1997) of quartz taken from various rocks and sediments in Japan, to discuss the possibilities of identifying sediment provenance. When the procedure is established, it will be useful to elucidate the provenance of sediments in the geohistorical environments, which may occasionally be related to stream piracy, regional tectonic setting and/or the environment changes of the hinterland.

\section{SAMPLES AND EXPERIMENTS}

Quartz grains for ESR measurements and TLCI observations were extracted from the metasediment (1 sample), the granitic rocks (12 samples) and the volcanic sediments (8 samples) of Jurassic to Quaternary (Fig. 1, Table 1) as follows; minerals of crushed rocks and sediments were sieved into 125-250 $\mu \mathrm{m}, 250-500 \mu \mathrm{m}$, $500 \mu \mathrm{m}-1 \mathrm{~mm}$ and $1-2 \mathrm{~mm}$ and then treated with hydrogen peroxide, hydrochloric acid, hydrofluoric acid and heavy liquid separation. Thereafter, the samples were aligned by grinding to grain size of $125-250 \mu \mathrm{m}$. We used $100 \mathrm{mg}$ of quartz grains for ESR measurement and approximately $10 \mathrm{mg}$ of quartz grains for TLCI measurement, respectively. All samples were irradiated by gamma ray to a dose of $2.5 \mathrm{kGy}$.

ESR spectra were recorded with an ESR spectrometer (TE-100, FA200; X-band JEOL RESONANCE Inc.), operating amplitude of field modulation $0.1 \mathrm{mT}$ at $100 \mathrm{kHz}$. The ESR signals of the $\mathrm{E}_{1}{ }^{\prime}$ centre is observed using a microwave power of $0.01 \mathrm{~mW}$ at room temperature (Fig. 2a). The signal of the $\mathrm{E}_{1}{ }^{\prime}$ centre were measured after heating the sample at $270^{\circ} \mathrm{C}$ for 15 minutes (the heat treated $\mathrm{E}_{1}^{\prime}$ centre), which corresponds to the number of oxygen vacancies (Shimada and Takada, 2008). The $\mathrm{E}_{1}{ }^{\prime}$ centre signal intensity of quartz is proportional to the age with higher value for quartz from older source rocks (Toyoda and Hattori, 2000; Toyoda and Naruse, 2002), reflecting the amount of the oxygen vacancies with an unpaired electron in a single silicon $\mathrm{sp}^{3}$ orbit (Feigl et al., 1974). Therefore it can be used to estimate the relative number of oxygen vacancies in quartz formed by natural radiation since its crystallization. The ESR signal of the $\mathrm{Al}$ centre (an electronic hole trapped at the bond between oxygen and $\mathrm{Al}$ which replaces $\mathrm{Si}$ ) and $\mathrm{Ti}-\mathrm{Li}$ centre (an electron trapped at $\mathrm{Ti}$ which replaces $\mathrm{Si}$, with accompanying $\mathrm{Li}$ ion) in quartz was measured with a microwave power of $5 \mathrm{~mW}$ at $77 \mathrm{~K}$ (Fig. 2b) using a finger dewar. We selected the relative height from the top of the first peak to the $16^{\text {th }}$ peak of the main hyperfine structures as the Al centre intensity (Yokoyama et al. 1985; Toyoda and Falguères, 2003) and the one from the baseline to the peak at $\mathrm{g}=1.913$ as the Ti-Li centre intensity (Toyoda et al., 2000). Measurements for the each centre signal intensity were performed five times and the average and the standard deviation were calculated. Quartz samples were constantly measured with the same standard of $\mathrm{MnO}$ marker. For the normalization and sensitivity correction, the average ESR intensity was divided by the weight of the sample and by the $\mathrm{MnO}$ marker signal intensity.

The TLCIs were taken with a digital camera within the temperature range 200-400 degree Celsius at a heating rate of 30 degree Celsius/s.

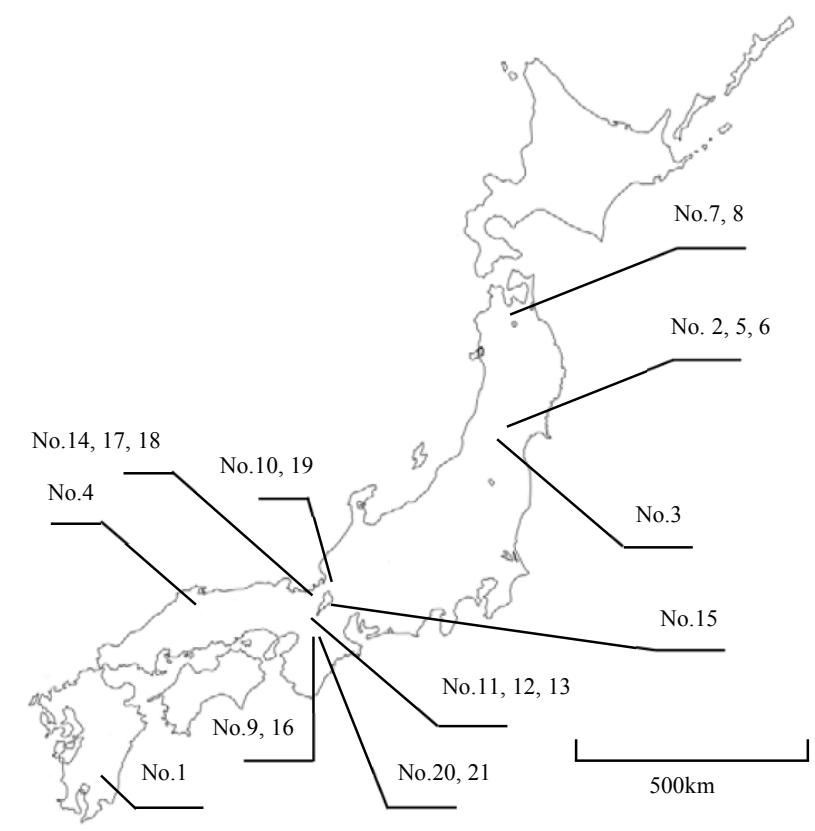

Fig. 1. Location map of the sampling sites in Japan. Sample names are given Table 1. 
Table 1. Sample number, name and age.

\begin{tabular}{|c|c|c|c|c|c|c|c|}
\hline No. & Sample & Type & grain size & $\begin{array}{c}\text { Al centre signal } \\
\text { intensity } \\
\text { (arb.units) } \\
\end{array}$ & $\begin{array}{c}\mathrm{Ti}-\mathrm{Li} \text { centre } \\
\text { signal intensity } \\
\text { (arb.units) }\end{array}$ & $\begin{array}{c}\mathrm{E}_{1}{ }^{\prime} \text { centre signal } \\
\text { intensity } \\
\text { (arb.units) } \\
\end{array}$ & Age \\
\hline 1 & Airaiwato tephra & $\begin{array}{l}\text { volcanic ash fall deposits } \\
\text { (non welded) }\end{array}$ & $0.5-1 \mathrm{~mm}$ & $3570 \pm 204$ & $1190 \pm 60$ & - & \multirow{8}{*}{ Quaternary } \\
\hline 2 & $\begin{array}{c}\text { Naruko-yanagisawa } \\
\text { tephra }\end{array}$ & $\begin{array}{l}\text { volcanic ash fall deposits } \\
\text { (non welded) }\end{array}$ & $0.5-1 \mathrm{~mm}$ & $3960 \pm 125$ & $1770 \pm 126$ & - & \\
\hline 3 & $\begin{array}{l}\text { Adachimedeshima } \\
\text { pumice fall deposits }\end{array}$ & $\begin{array}{c}\text { pumice fall deposits } \\
\text { (non welded) }\end{array}$ & $0.5-1 \mathrm{~mm}$ & $3580 \pm 210$ & $793 \pm 56$ & $0.63 \pm 0.05$ & \\
\hline 4 & $\begin{array}{c}\text { Ohta pyroclastic flow } \\
\text { deposits }\end{array}$ & $\begin{array}{l}\text { pyroclastic flow deposits } \\
\text { (non welded) }\end{array}$ & $0.5-1 \mathrm{~mm}$ & $1590 \pm 107$ & $595 \pm 73$ & $0.52 \pm 0.04$ & \\
\hline 5 & $\begin{array}{c}\text { Hiraizumi pumice } \\
\text { layer }\end{array}$ & $\begin{array}{c}\text { pumice fall deposits } \\
\text { (non welded) }\end{array}$ & $0.5-1 \mathrm{~mm}$ & $4350 \pm 147$ & $870 \pm 63$ & - & \\
\hline 6 & Naruko-Nisaka tephra & $\begin{array}{l}\text { volcanic ash fall deposits } \\
\text { (non welded) }\end{array}$ & $0.5-1 \mathrm{~mm}$ & $3020 \pm 76$ & $975 \pm 86$ & $1.36 \pm 0.04$ & \\
\hline 7 & $\begin{array}{l}\text { Hakkoda 1st-stage } \\
\text { pumice fall deposits }\end{array}$ & $\begin{array}{c}\text { pumice fall deposits } \\
\text { (non welded) }\end{array}$ & $0.5-1 \mathrm{~mm}$ & $2960 \pm 169$ & $1080 \pm 109$ & $0.40 \pm 0.04$ & \\
\hline 8 & $\begin{array}{l}\text { Hakkoda 1st-stage } \\
\text { pyroclastic flow de- } \\
\text { posits }\end{array}$ & $\begin{array}{l}\text { pyroclastic flow deposits } \\
\text { (non welded) }\end{array}$ & $0.5-1 \mathrm{~mm}$ & $5980 \pm 202$ & $3130 \pm 155$ & $0.65 \pm 0.07$ & \\
\hline 9 & $\begin{array}{l}\text { Muro pyroclastic flow } \\
\text { deposits }\end{array}$ & $\begin{array}{l}\text { pyroclastic flow deposits } \\
\text { (welded) }\end{array}$ & $\begin{array}{c}0.5-1 \mathrm{~mm} \\
250-500 \mu \mathrm{m} \\
125-250 \mu \mathrm{m} \\
\end{array}$ & $\begin{array}{l}8750 \pm 135 \\
8560 \pm 119 \\
8950 \pm 184 \\
\end{array}$ & $\begin{array}{l}1832 \pm 77 \\
1770 \pm 89 \\
1760 \pm 73 \\
\end{array}$ & $\begin{array}{l}3.40 \pm 0.11 \\
3.81 \pm 0.16 \\
3.83 \pm 0.04 \\
\end{array}$ & Neogene \\
\hline 10 & Koujyaku granite & granitic rock & $\begin{array}{c}1-2 \mathrm{~mm} \\
0.5-1 \mathrm{~mm} \\
250-500 \mu \mathrm{m} \\
\end{array}$ & $\begin{array}{l}3200 \pm 286 \\
2690 \pm 159 \\
3110 \pm 151 \\
\end{array}$ & $\begin{array}{l}429 \pm 27 \\
345 \pm 24 \\
139 \pm 17 \\
\end{array}$ & $\begin{array}{l}37.1 \pm 0.71 \\
24.5 \pm 0.74 \\
37.0 \pm 0.71 \\
\end{array}$ & Paleogene \\
\hline 11 & Yagyu granite & granitic rock & $\begin{array}{c}1-2 \mathrm{~mm} \\
0.5-1 \mathrm{~mm} \\
250-500 \mu \mathrm{m}\end{array}$ & $\begin{array}{c}4450 \pm 79 \\
- \\
4230 \pm 194\end{array}$ & $\begin{array}{c}1100 \pm 50 \\
- \\
918 \pm 73\end{array}$ & $\begin{array}{c}7.74 \pm 0.20 \\
5.97 \pm 0.03 \\
11.20 \pm 0.79 \\
\end{array}$ & \multirow{10}{*}{ Cretaceous } \\
\hline 12 & Shigaraki granite A & granitic rock & $\begin{array}{c}1-2 \mathrm{~mm} \\
0.5-1 \mathrm{~mm} \\
250-500 \mu \mathrm{m} \\
\end{array}$ & $\begin{array}{c}5170 \pm 96 \\
4810 \pm 246 \\
4570 \pm 125 \\
\end{array}$ & $\begin{array}{l}570 \pm 21 \\
427 \pm 25 \\
320 \pm 61\end{array}$ & $\begin{array}{l}12.8 \pm 0.22 \\
18.8 \pm 0.81 \\
33.5 \pm 1.29 \\
\end{array}$ & \\
\hline 13 & Shigaraki granite B & granitic rock & $\begin{array}{c}1-2 \mathrm{~mm} \\
0.5-1 \mathrm{~mm} \\
250-500 \mu \mathrm{m} \\
\end{array}$ & $\begin{array}{c}2190 \pm 54 \\
1860 \pm 59 \\
2760 \pm 120 \\
\end{array}$ & $\begin{array}{l}254 \pm 25 \\
169 \pm 20 \\
336 \pm 31 \\
\end{array}$ & $\begin{array}{c}- \\
16.1 \pm 0.60 \\
- \\
\end{array}$ & \\
\hline 14 & Hira granite & granitic rock & $\begin{array}{c}1-2 \mathrm{~mm} \\
0.5-1 \mathrm{~mm} \\
250-500 \mu \mathrm{m} \\
\end{array}$ & $\begin{array}{l}3240 \pm 179 \\
2640 \pm 117 \\
2930 \pm 120 \\
\end{array}$ & $\begin{array}{c}227 \pm 20 \\
201 \pm 9 \\
139 \pm 7\end{array}$ & $\begin{array}{l}50.3 \pm 0.59 \\
26.1 \pm 0.64 \\
49.3 \pm 0.58 \\
\end{array}$ & \\
\hline 15 & Suzuka granite & granitic rock & $\begin{array}{c}1-2 \mathrm{~mm} \\
0.5-1 \mathrm{~mm} \\
250-500 \mu \mathrm{m} \\
\end{array}$ & $\begin{array}{c}7220 \pm 99 \\
7110 \pm 156 \\
7800 \pm 218 \\
\end{array}$ & $\begin{array}{c}958 \pm 31 \\
1010 \pm 60 \\
788 \pm 40\end{array}$ & $\begin{array}{l}41.3 \pm 1.14 \\
33.0 \pm 0.61 \\
41.1 \pm 1.13 \\
\end{array}$ & \\
\hline 16 & Joryu Tonalite & granitic rock & $0.5-1 \mathrm{~mm}$ & $11400 \pm 204$ & $839 \pm 38$ & $28.6 \pm 0.49$ & \\
\hline 17 & Hiei granite $A$ & granitic rock & $\begin{array}{c}1-2 \mathrm{~mm} \\
0.5-1 \mathrm{~mm} \\
\end{array}$ & $\begin{array}{c}5660 \pm 90 \\
6250 \pm 181 \\
\end{array}$ & $\begin{array}{c}1370 \pm 56 \\
1300 \pm 108\end{array}$ & $\begin{array}{l}34.3 \pm 1.69 \\
19.5 \pm 0.59 \\
\end{array}$ & \\
\hline 18 & Hiei granite B & granitic rock & $\begin{array}{c}1-2 \mathrm{~mm} \\
0.5-1 \mathrm{~mm} \\
250-500 \mu \mathrm{m}\end{array}$ & $\begin{array}{c}5490 \pm 79 \\
- \\
6100 \pm 130 \\
\end{array}$ & $\begin{array}{c}1230 \pm 45 \\
- \\
1020 \pm 105\end{array}$ & $\begin{array}{l}33.9 \pm 1.01 \\
21.2 \pm 0.75 \\
33.7 \pm 1.01 \\
\end{array}$ & \\
\hline 19 & Kaitukiyama granite & granitic rock & $\begin{array}{c}1-2 \mathrm{~mm} \\
0.5-1 \mathrm{~mm} \\
250-500 \mu \mathrm{m}\end{array}$ & $\begin{array}{l}4960 \pm 130 \\
5530 \pm 126 \\
5270 \pm 109 \\
\end{array}$ & $\begin{array}{c}2230 \pm 98 \\
2400 \pm 220 \\
1880 \pm 121\end{array}$ & $\begin{array}{l}15.7 \pm 0.39 \\
17.0 \pm 0.81 \\
37.1 \pm 1.54 \\
\end{array}$ & \\
\hline 20 & Ao granite & granitic rock & $\begin{array}{c}0.5-1 \mathrm{~mm} \\
250-500 \mu \mathrm{m}\end{array}$ & $\begin{array}{l}4950 \pm 130 \\
5740 \pm 386\end{array}$ & $\begin{array}{l}59.70 \pm 8 \\
64.40 \pm 5\end{array}$ & $\begin{array}{c}41.0 \pm 1.90 \\
-\end{array}$ & \\
\hline 21 & $\begin{array}{l}\text { Metamudstone with } \\
\text { sandstone }\end{array}$ & metasediment & $\begin{array}{c}0.5-1 \mathrm{~mm} \\
250-500 \mu \mathrm{m}\end{array}$ & $\begin{array}{l}4640 \pm 205 \\
4780 \pm 157\end{array}$ & $\begin{array}{l}600 \pm 31 \\
623 \pm 35\end{array}$ & $\begin{array}{l}18.6 \pm 0.19 \\
18.6 \pm 0.86\end{array}$ & Jurassic \\
\hline
\end{tabular}



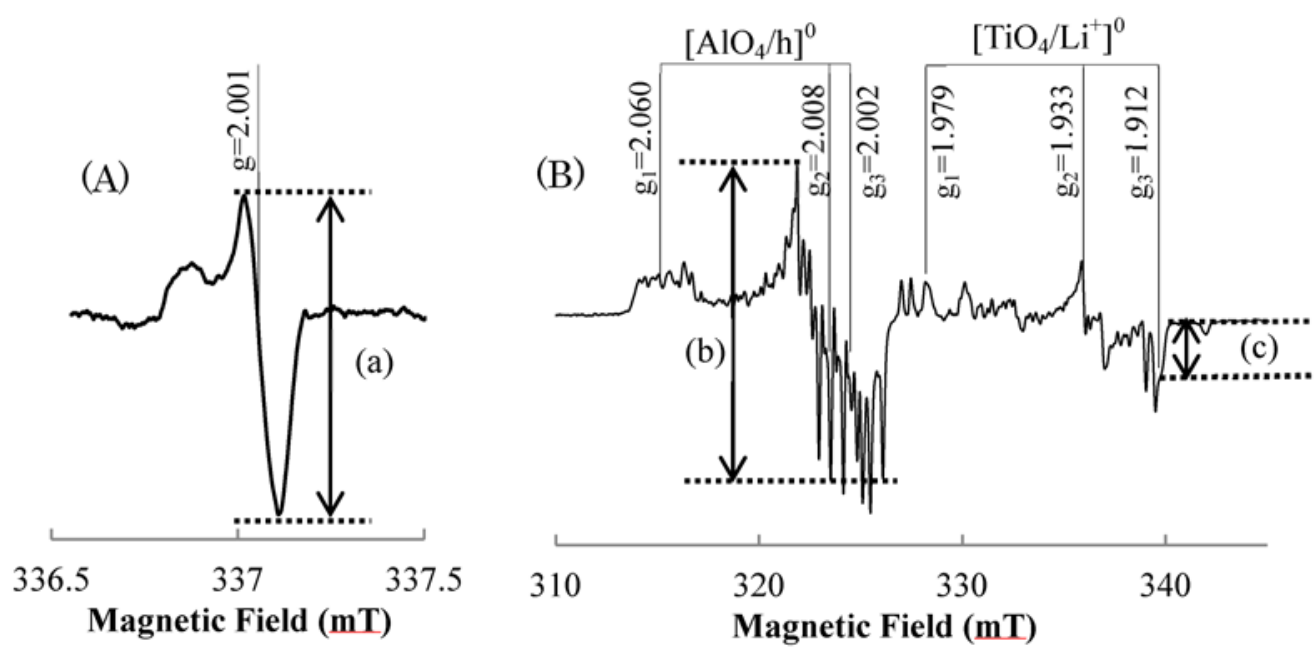

Fig. 2. (A) $E_{1}{ }^{\prime}$ centre signal was observed at room temperature for a sample of Kaitukiyama granite. (B) Al and Ti-Li centre signals were observed at $77 \mathrm{~K}$ for a sample of Hiraizumi pumice layer. (a) $E_{1}$ ' centre signal intensity; (b) Al centre signal intensity; (c) Ti-Li centre signal intensity.

\section{RESULT AND DISSCUSION}

\section{Difference among the ESR signal intensities due to the provenance of the sample}

Fig. 3 shows a plot of the Al versus the Ti-Li centre signal intensities observed in quartz of the samples. Fig. 4 shows the heat treated $E_{1}$ ' centre signal intensity of each sample. The Al centre signal from quartz grains included in Ohta pyroclastic flow deposits (No.4 in Table 1) shows the lowest intensity among all the samples (No.4 in Fig. 3). The Al centre signal from quartz grains included in Joryu Tonalite (No.16 in Table 1) shows the highest intensity among all the samples (No.16 in Fig. 3). The Ti-Li centre signal from quartz grains included in Ao granite (No.20 in Table 1) shows the lowest intensity among all the samples (No.20 in Fig. 3). The Ti-Li centre signal from quartz grains included in Hakkoda $1^{\text {st }}-$ stage pyroclastic flow deposits (No.8 in Table 1) shows the highest intensity among all the samples (No.8 in Fig. 3). The points for volcanic rocks and tephra tend to be plotted in upper parts while those for granitic rocks tend to be in lower right (Fig. 3). The $\mathrm{E}_{1}{ }^{\prime}$ centre signal from quartz grains included in Hira granite (No.14 in Table 1) shows the highest intensity among all the samples (No.14 in Fig. 3). The Quaternary sample of volcanic sediment (No. 3, 4, 6, 7 and 8 in Fig. 4) show similar low intensities close to the noise level, being difficult to distinguish one from another. The similar result was reported by using Quaternary samples of volcanic rocks from Kozu Island in Tokyo, Japan (Shimada and Takada, 2008). Though Shigaraki granite A and B (No.12 and 13 in Table 1) are the same granitic body, sampling point is different. These $\mathrm{Al}$ and Ti-Li centre signals intensities are different. Moreover both of the $\mathrm{E}_{1}{ }^{\prime}$ one is the similar (No.12 and 13 in Fig. 3). Hakkoda $1^{\text {st }}$ - stage pyroclastic flow deposits and

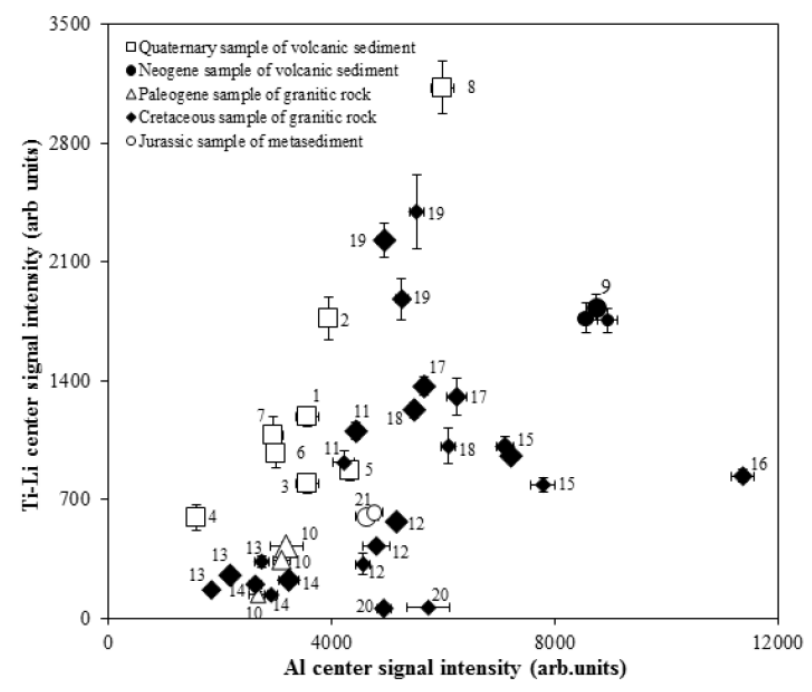

Fig. 3. Diagram of Al versus Ti-Li centre signal intensities of quartz grains in various samples. The size of symbol represents the grain diameter: maximum one is 1-2 mm, and minimum one is 125-250 $\mu \mathrm{m}$.

Hakkoda $1^{\text {st }}$-stage pyroclastic fall pumice deposits (No.7 and 8 in Table 1) are taken from the same sampling site. The $\mathrm{Al}$ and $\mathrm{Ti}-\mathrm{Li}$ centre signals from quartz grains included in those volcanic materials are different from on another whereas the $\mathrm{E}_{1}{ }^{\prime}$ ones are the similar (No.7 and 8 in Fig. 3).

\section{Difference among the ESR signal intensities due to grain size of the sample}

The ESR signal intensity of quartz sometimes has a large standard deviation (No.19 and 20 in Fig. 3). The ESR signal intensities of samples are different according to the grain size (e.g. No.11, 12, 17 and 18 in Fig. 3 and 


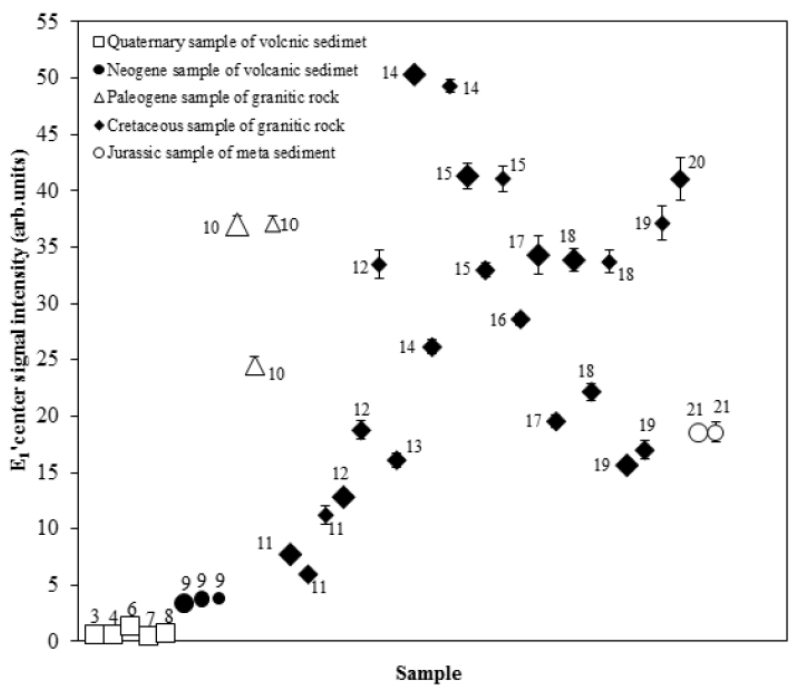

Fig. 4. E' centre intensities of quartz. The size of symbol represents the grain diameter, maximum one is 1-2 mm, and minimum one is 125$250 \mu m$.

No.10, 14 and 17-19 in Fig. 4). The Al centre signal intensity of Shigaraki granite B (No.13 in Table 1) ranged between 1860 and 2760 (average, 2270). The TiLi centre signal intensity of Kaitsuki granite (No.19 in Table 1) ranged between 1880 and 2400 (average, 2170). The $E_{1}{ }^{\prime}$ centre signal intensity of Hira granite (No.14 in Table 1) ranged between 26.10 and 50.30 (average, 41.90). Those variations are the largest among the present samples. ESR signal intensities of Muro pyroclastic flow deposits (No.9 in Table 1) are consistent within the range of error for 3 grain sizes (No.9 in Fig. 3 and Fig. 4). ESR signal intensities of Metamudstone with sandstone (No.9 in Table 1) are consistent within the range of error for 2 grain sizes (No.21 in Fig. 3 and Fig. 4). The Quaternary sample of volcanic sediment (No. 3, 4, 6, 7 and 8 in Fig. 4) show similar low intensities close to the noise level, being difficult to distinguish one from another. It indicates that we can identify more clearly the source of same grain size in quartz of samples using both the $E_{1}$ ' centre signal intensities and the diagram of the Al versus Ti-Li centre signal intensities.

Therefore, it indicates that we should use the multiple indexes of the ESR signal intensities for estimating detailed sediment provenance.

\section{TLCI}

TLCIs of the samples show different emission colours (Fig. 5). The emission colour of TL from Quaternary and Neogene samples of volcanic sediment (No.1-9 in Fig. 5) and some samples of granitic rock (No. 10 and 14 in Fig. 5) are almost red on the TLCIs though the emission intensities were different. The emission colour of TL from the rest of granitic rocks and metamudstone quartz were blue on the TLCIs though the emission intensities were different (No. 11-13, 16, 17 and 19-21 in Fig. 5). The TL from the quartz included in Muro pyroclastic flow deposits and Koujyaku granite (No.9 and 10 in Table 1) shows almost red with a few blue colours (No. 9 and 10 in Fig. 5). The quartz of Suzuka granite (No.15 in Table 1) shows mixed red and blue TL on the TLCI (No. 15 in Fig. 5).

\section{Multiple ESR centre signal approach and TLCIs to identify the source of quartz}

As mentioned before, the ESR signal intensity of the $E_{1}^{\prime}$ centre in the granitic quartz varies sample to sample, except for that in Quaternary tephra samples, which is so low close to the noise level. It was found that the diagram, ESR intensities of $\mathrm{Al}$ versus $\mathrm{Ti}-\mathrm{Li}$ centre signal intensities, distinguish volcanic from the same grain size in granitic quartz as well as distinguish individual tephra from another. The data plotted in Figs. 3 and 4 show distinct distributions, raising possibility that the source of quartz could be identified in greater detail if we combine measurements of the $\mathrm{Al}$ and $\mathrm{Ti}-\mathrm{Li}$ centre signals of the same grain size in quartz grains with those of the $E_{1}{ }^{\prime}$ centre signal. They also suggest that we should consider the grain size to identify the source of quartz using the ESR signal intensity. This "multiple-centre signal approach" of ESR measurement should be further studied for estimating detailed sediment provenance at the drainage scale.

The emission colour of TL from volcanic quartz and some granitic quartz samples is almost red and that from the rest of granitic and metamudstone quartz is blue as results of TLCI although the emission intensities are different. The red emission of TLCIs in granitic rocks was different from the results of Hashimoto et al. (1997) and Ganzawa et al. (1997). It is suggested that those colour emission of TL are related to Al impurities (e.g. Yawata et al., 2006) or Europium ion (e.g. Ohta et al., 1992). It indicates that the TLCIs are also effective to identify the source of quartz and estimate sediments provenance. These findings raise the possibility of identifying details of sediment provenance from the combination of the multiple ESR centre signal approach and TLCIs.

Sawakuchi et al. (2011) suggests that the temperature of crystallization and the number of cycles of burial and solar exposure may be the main natural factors controlling the optically stimulated luminescence (OSL) sensitivity of quartz grains. It also suggests that the increase in OSL sensitivity due to cycles of erosion and deposition surpasses the sensitivity inherited from the source rock, with this increase being mainly related to the sensitization of fast OSL components. In addition to the multiple ESR centre signal approach and TLCIs, using OSL signal for grains from the same sedimentary unit may enable an assessment of detailed sediment provenance at the drainage scale. 


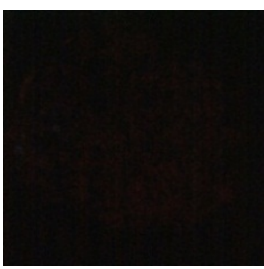

(1)Airaiwato tephra

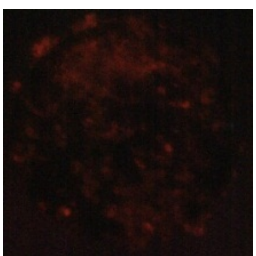

(6) Naruko-Nisaka tephra

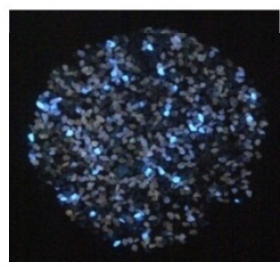

(11) Yagyu granite

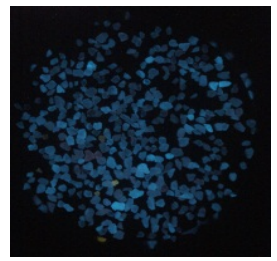

(16) Jyoryu tonalite

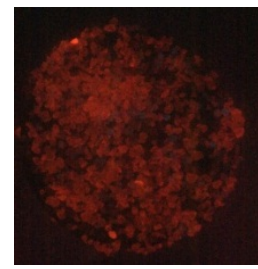

(2) tephra

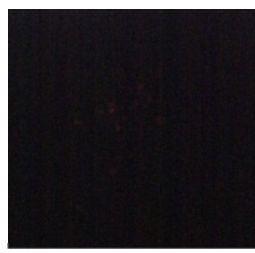

(7) Hakkoda $1^{\text {st }}$-stage pumice fall deposits

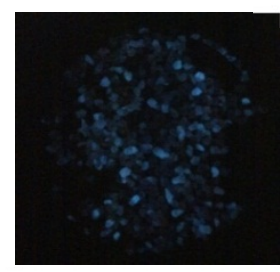

(12) Shigaraki granite A

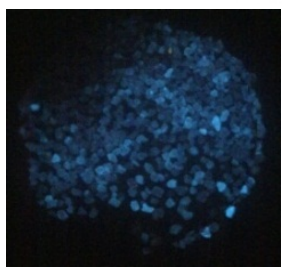

(17) Hiei granite A

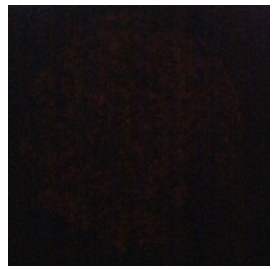

(3) Adachimedeshima pumice fall deposits

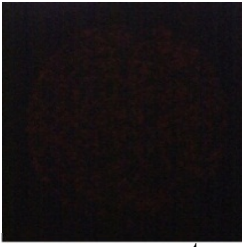

(8) Hakkoda $1^{\text {st }}$-stage pyroclastic flow deposits

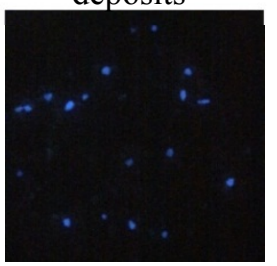

(13) Shigaraki granite B

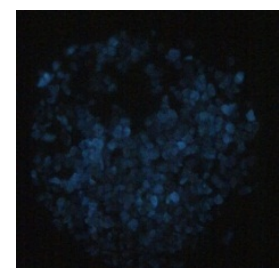

(19) Kaitukiyama granite

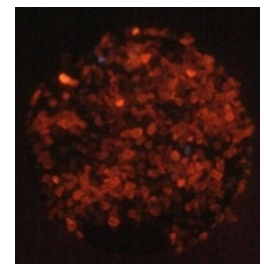

(4) Ohta pyroclastic flow deposits

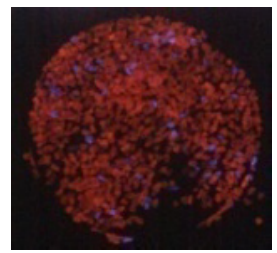

(9) Muro pyroclastic flow deposits

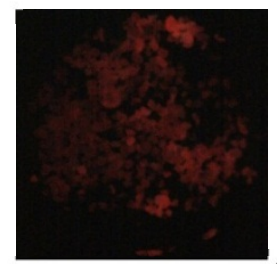

(14) Hira granite

(15) Suzuka granite

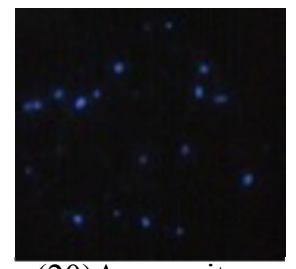

(20)Ao granite

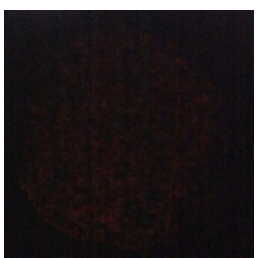

(5) Hiraizumi pumice layer

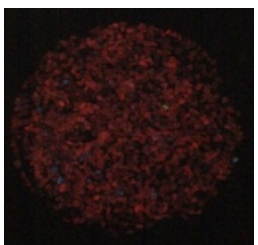

(10) Koujyaku granite
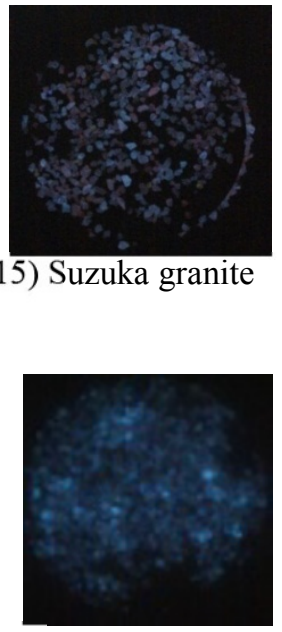

(21) Metamudstone with sandstone

Fig. 5. TLCls of quartz grains in various samples.

\section{CONCLUSION}

The $E_{1}$ ' centre signal intensity of the same grain size in granitic quartz is mostly different from each other, but that of the Quaternary samples of volcanic sediment shows similar low intensity close to the amplitude of noise on the baseline, being difficult to distinguish each other (Fig. 4). However on the ESR diagram of the Al versus the Ti-Li centre signal intensities we can roughly distinguish Quaternary samples of volcanic sediment from the same grain size in granitic one and identify the peculiar domain of each sample (Fig. 3). Therefore, it is necessary that the same grain size in samples is confirmed distribution trend of ESR signal intensity.
The TLCIs from Quaternary and Neogene samples of volcanic sediment (No.1-9 in Fig. 5) and some granitic quartz samples (No. 10 and 14 in Fig. 5) is almost red and that from the rest of granitic and metamudstone quartz is blue on the TLCIs though the emission intensities is different (No. 11-13, 16, 17 and 19-21 in Fig. 5). The TL from the quartz included in Muro pyroclastic flow deposits and Koujyaku granite (No.9 and 10 in Table 1) shows almost red with a few blue colours (No. 9 and 10 in Fig. 5). The quartz of Suzuka granite (No.15 in Table 1) shows mixed red and blue TL on the TLCI (No. 15 in Fig. 5).

Our results suggest that the detection of the multicentre signal intensities of ESR and the TLCIs are effective to identify the source of quartz and estimate sediments provenance. 


\section{REFERENCES}

Aitken MJ, 1985. Thermoluminesence dating. Academic Press. London, $359 \mathrm{p}$.

Aitken MJ, 1998. An introduction to optical dating. Oxford Science Publications, 267p.

Feigl FJ, Fowler WB and Yip KL, 1974. Oxygen vacancy model for the $\mathrm{E}_{1}$ ' centre in $\mathrm{SiO}_{2}$. Solid State Communications 14(3): 225-229, DOI 10.1016/0038-1098(74)90840-0.

Ganzawa Y, Watanabe Y, Osanai F and Hashimoto T, 1997. TL colour images from quartzes of loess and tephra in China and Japan. $R a$ diation Measurements 27(2): 383-388, DOI 10.1016/S13504487(96)00129-1.

Hashimoto T, Koyanagi A, Yokosaka K, Hayashi Y and Sotobayashi T, 1986. Themoluminecence colour images from quartz of beach sands. Geochemical Journal 20(3): 111-118.

Hashimoto T, Katayama H, Sakaue H, Hase H, Arimura T and Ojima T, 1997. Dependence of some radiation-induced phenomena from natural quartz on hydroxyl-impurity contents. Radiation Measurements 27(2): 243-250, DOI 10.1016/S1350-4487(96)00115-1.

Ikeya M, 1993. New Applications of Electron Spin Resonance, Dating, Dosimetry, and Microscopy. World Scientific, Singapore, 500p.

Duttinea M, Villeneuvea G, Bechtela F and Demazeaub G, 2002. Caractérisation par résonance paramagnétique électronique (RPE) de quartz naturels issus de différentes sources (Characterization by electron paramagnetic resonance (EPR) of natural quartz, problem of source differentiation). Comptes Rendus Geoscience 334(13): 949-955, DOI 10.1016/S1631-0713(02)01845-X.

Murata K and M Norman, 1976. An index of crystallinity for quartz. American Journal of Science 276(9): 1120-1130, DOI 10.2475/ajs.276.9.1120.

Nagashima K, Tada R, Tani A, Toyoda S, Sun Y, and Isozaki Y, 2007. Contribution of aeolian dust in Japan Sea sediments estimated from ESR signal intensity and crystallinity of quartz. Geochemistry, Geophysics, Geosystems 8(2), DOI 10.1029/2006GC001364.

Naruse T, Ono Y, Hirakawa K, Okashita M, and Ikeya M, 1997. Source areas of eolian dust quartz in East Asia: a tentative reconstruction of prevailing winds in isotope stage 2 using electron spin resonance. Geographical review of Japan 70A-1: 15-27.

Ohta M, Asami S and Sakaguchi M, 1992. Luminescence and ESR Characteristics of Glaserite Crystals Doped with Europium Ion. Denki Kagaku oyobi Kogyo Butsuri Kagaku 60(7): 643-648.

Sawakuchi AO, Blair MW, DeWitt R, Faleiros FM, Hyppolito T and Guedes CCF, 2011. Thermal history versus sedimentary history: OSL sensitivity of quartz grains extracted from rocks and sediments. Quaternary Geochronology 6(2): 261-272, DOI 10.1016/j.quageo.2010.11.002.

Toyoda S and Hattori M, 2000. Formation and decay of the $E_{1}$ ' centre and of its precursor. Applied Radiation and Isotopes 52(5): 13511356, DOI 10.1016/S0969-8043(00)00094-4.

Toyoda S and Naruse T, 2002. Eolian Dust from Asia Deserts to Japanese Island since the last Glacial Maximum: the Basis for the ESR Method. Japan Geomorphological union 23-5: 811-820.

Toyoda S and Falguères $\mathrm{C}, 2003$. The method to represent the ESR intensity of the aluminium hole centre in quartz for the purpose of dating. Advances in ESR applications 20: 7-10.

Toyoda S, Voinchet P, Falguères C, Dolo JM and Laurent M, 2000. Bleaching of ESR signals by the sunlight: a laboratory experiment for establishing the ESR dating of sediments. Applied Radiation and Isotopes 52(5): 1357-1362, DOI 10.1016/S09698043(00)00095-6.

Shimada A and Takada M, 2008. Characteristics of Electron Spin Resonance (ESR) signals in quartz from igneous rock samples: a clue to sediment provenance. Annual Reports of Graduate School of Humanities and Sciences 23: 187-195.

Yawata T, Takeuchi T and Hashimoto T, 2006. Dependence of luminescence sensitivity of quartz on $\alpha-\beta$ phase inversion berak temperatures. Radiation Measurements 41(7-8): 841-846, DOI 10.1016/j.radmeas.2006.05.008.

Yokoyama Y, Falguères C and Quaegebeur JP, 1985. ESR dating of quartz from quaternary sediments: first attempt. Nuclear Tracks and Radiation Measurements 10(4-6): 921-928, DOI 10.1016/0735-245X (85)90109-7. 